\title{
Powłoki dla ochrony przed zużyciem elementów maszyn i urządzeń
}

\section{Coatings for protection against wear of machinery}

\section{Streszczenie}

Dokonano analizy przyczyn zużycia maszyn i urządzeń oraz przedstawiono możliwości ograniczania zużywania się elementów poprzez wytwarzanie na ich powierzchniach plazmowo natryskiwanych powłok z mieszanin najtwardszych materiałów z miękką fazą wiążącą, tworzącą metalurgiczne połączenie z podłożem.

Przeprowadzono pomiary mikrotwardości oraz odporności na zużycie ścierne i erozyjne wytypowanych powłok ceramicznych i cermetalowych Uzyskane wyniki porównano z wynikami ścierania stalowych próbek - uzyskując dla powłok znaczący wzrost odporności.

Wytypowanymi powłokami natryskano elementy maszyn i urządzeń, poddano je eksploatacji przemysłowej. Uzyskane wyniki uzasadniają celowość wytwarzania powłok na elementach maszyn i urządzeń.

Słowa kluczowe: powłoki ochronnne, zużycie, natryskiwanie plazmowe

\section{Abstract}

The mechanism is described of corrosive processes occurring on the heated walls of boilers, both at low temperatures, i.e. in the furnace zone, and at medium temperatures, i.e. on the steam superheater surfaces. Further part of the work analyzes the processes of pitting corrosion occurring in the presence of the oxides of nitrogen, sulfur, and chlorine, which dissolve in water vapour condensing on the metal walls of heat equipment under the furnace lining. Moreover, the causes of the erosive wear of heat equipment walls are described.

The examination were carried out of the properties of plasma sprayed ceramic and cermet coatings that are marked by the ability of forming a tight barrier impermeable to corrosive agents. The measurements were made, including porosity, erosive wear resistance, and the ability of reducing steel substrate corrosion. Based on the results obtained, the evaluation was performed of the usefulness of coatings for reducing the wear processes of heat equipment metal walls. Results from the industrial operation of elements with protective coatings are reported.

Keywords: protection coatings, wear, plasma spraying

\section{Przyczyny i rodzaje zużycia elemnetów maszyn i urządzen}

Zużycie elementów maszyn i urządzeń jest procesem niszczenia ich powierzchni. Proces ten wywołany jest m.in.: tarciem, korozją (chemiczną i elektrochemiczną), zmęczeniem oraz oddziaływaniem temperatury w szczególności jej zmianami i różnicami na przekrojach elementów[1 $\div 3]$. W związku z powyższym wyróżnia się następujące rodzaje zu-

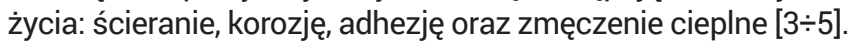

\section{Rodzaje zużycia}

Zużycie ścierne - obejmuje warstwę powierzchniową współpracujących elementów i jest wynikiem skrawającego, ściskającego i rysującego oddziaływania nierówności powierzchni bądź ziaren obcych materiałów znajdujących się między płaszczyznami objętych tarciem.
Oddziaływanie to wywołuje ubytek masy elementów oraz uszkodzenia ich powierzchni objawiające się powstaniem zagłębień. Zakres zużycia ściernego można ograniczyć poprzez utwardzenie powierzchni osiągane przez: nawęglanie, azotowanie, hartowanie bądź przez wytwarzanie twardych powłok.

Podstawowym parametrem charakteryzującym tarcie jest współczynnik tarcia określany stosunkiem siły tarcia do wartości obciążenia normalnego (towarzyszącemu tarciu).

Przykładowo, kształtowanie się wartości tego parametru przedstawiono na rysunku 1.

Z racji dużej porowatości otwartej powłok (chropowatości powierzchni) posiadają one zdolność do długotrwałego przechowywania smarów co zapobiega zatarciu współpracujących elementów. Jednocześnie twarde ziarna (węglików, borków, azotków, niektórych tlenków) tworzące powłoki przenoszą obciążenia trących się elementów, a nieliczne

dr inż. Sławomir Morel - Politechnika Częstochowska. 
wykruszające się w czasie pracy z osnowy powłoki ziarna po ich ewentualnym przemieszczeniu się po powierzchni powłoki z reguły pracują nadal (dzięki jej porowatości).

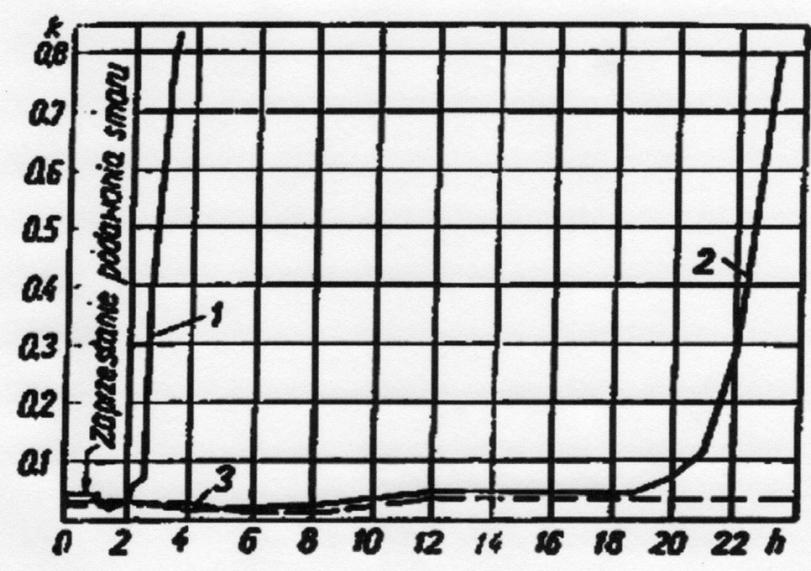

Rys. 1. Zmiana współczynnika tarcia $k$ stalowego wału po zaprzestaniu smarowania [1]: 1 - bez powłoki, 2 - z powłoką natryskaną ze stali, 3 - z powłoką natryskaną z proszku na bazie grafitu

Fig. 1. Friction coefficient $k$ of steal shaft without lubrication in function of time: 1 - without coating, 2 - with thermal sprayed coating, 3 - with thermal sprayed coating based on graphite powder

Zużycie adhezyjne - występuje przy tarciu ślizgowym elementóweksploatowanych przy dużych naciskach które przemieszczają się ze względnie małymi prędkościami. Proces ten wywołany jest powstawaniem i niszczeniem połączeń adhezyjnych miedzy współpracującymi elementami i towarzyszą mu uszkodzenia objawiające się wyrwaniem bądź wykruszeniem powierzchni. Zdolność do sczepiania się zależy od rodzaju materiałów ich budowy strukturalnej. Ważnym czynnikiem decydującym o zużyciu adhezyjnym jest zdolność metali do tworzenia warstewek tlenków, które cechują się wiązaniami o charakterze niemetalicznym a które zapobiegają tworzeniu się sczepień adhezyjnych.

Do głównych sposobów zapobiegania zużyciu adhezyjnemu należą:

- zwiększenie twardości elementów ulegających zużyciu,

- wytwarzanie elementów z materiałów o małej zdolności do sczepiania,

- wytwarzanie warstw niemetalicznych oraz stosowanie obróbki cieplno-chemicznej,

- zapewnienie dobrego smarowania.

Zużycie korozyjne - w obszarach tarcia współpracujących elementów wskutek absorpcji tlenu na ich powierzchniach powstają pasywne warstewki tlenków, które niezbyt łatwo oddzielają się od metalowego podłoża. Ten rodzaj zużycia występuje zarówno przy tarciu ślizgowym jak i tocznym. Intensywność tego procesu jest stosunkowo mała stąd dość często dąży się do osiągnięcia warunków sprzyjających temu rodzajowi zużycia i do jednoczesnego wyeliminowania innych rodzajów zużycia.

Zużycie erozyjne - wiele elementów urządzeń pracuje w środowisku przepływających płynów, które najczęściej „unoszą" pyły, zastygłe krople metali i żużli oraz inne drobnoziarniste materiały - ogólnie nazwane ścierniwem. Wskutek dynamicznego działania (wywołanego prędkością przepływu) strugi transportowanego ścierniwa z określoną szybkością zostaje ono zderzane z "omywaną" powierzchnią. Niezależnie od kąta padania ścierniwa występuje ścieranie strumieniem ślizgającym się po „omywanej” powierzchni elementu. Ten rodzaj zużycia określa się nazwą erozji.

Przykładowo w hutnictwie nad konwertorami do wytapiania stali oraz miedzi instaluje się kotły przeznaczone do odzysku ciepła gazów konwertorowych. Zapylenie gazów z reguły przekracza $50 \mathrm{~g} / \mathrm{m}^{3}$. Są to drobne krople metalu i żużla unoszone przez gazy konwertorowe na wysokość do kilkudziesięciu metrów. Skutkiem ostygania gazów (zwłaszcza w strefie przyściennej) następuje ich wytrącanie się. Zastygłe krople osuwając się po ścianach wywołują ich intensywną erozję. Powierzchnie kotła stają się metalicznie błyszczone, przez co ich zdolność do absorpcji ciepła spalin jest mała (współczynnik emisyjności wynosi ok. 0,3).

Zużycie kawitacyjne - przy szybkim przemieszczaniu się elementów urządzeń u cieczach lub parach (łopatki: wentylatorów, turbin, ruchome części pomp itp.) występuje zużycie kawitacyjne. Ten rodzaj zużycia zaliczyć należałoby do zużycia zmęczeniowego, gdyż towarzyszą mu udary $\mathrm{np}$. łopatek o krople cieczy a zużywana łopatka podlega obciążeniom dynamicznym.

Mechanizmy zużycia erozyjnego i zmęczeniowego wywołanego kawitacją niejednokrotnie występują łącznie.

\section{Możliwości ograniczenia procesów zużycia}

Dla każdego rodzaju zużycia i zróżnicowanych intensywności tych procesów uwarunkowanych parametrami eksploatacyjnymi należy dobrać właściwe materiały oraz zastosować adekwatne metody ulepszania własności elementów bądź to drogą stosowanych obróbek cieplno-chemicznych lub poprzez wytworzenie powłok. Pożądane wyniki w tym zakresie uzyskuje się eksperymentalnie, prze czym najbardziej miarodajnymi są te które uzyskuje się w warunkach

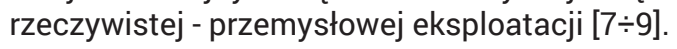

Poszczególne materiały cechuje z reguły odporność na ściśle określony rodzaj zużycia. I tak przykładowo powłoki ceramiczne $\mathrm{z} \mathrm{Al}_{2} \mathrm{O}_{3}, \mathrm{Cr}_{2} \mathrm{O}_{3}, \mathrm{WC}, \mathrm{Cr}_{3} \mathrm{C}_{2}$ oraz ich mieszanin posiadają dużą odporność na ścieranie. Jednakże są one nieprzydatne przy zużyciu udarowym (rolki samotoków walcowniczych). Również niewskazane jest stosowanie ceramicznych powłok na elementach podlegających dużym szokom termicznym. Ich odporność na udary bądź na szoki termiczne ulega radykalnej poprawie po wprowadzeniu do ceramiki metalowego dodatku miękkiej - osnowy. Wówczas w strukturze powłoki wystąpią twarde ziarna otoczone osnową bogatą w miękką fazę którą tworzą: Co, Ni, Al., NiCr, NiAl itd. Odporne na zużycie ścierne twarde ziarna tlenków bądź węglików zmieszane z metalicznymi materiałami tworzącymi miękką fazę stanowią podstawę wytwarzania cermetalowych powłok, których zakres przemysłowych zastosowań przewyższa znacznie

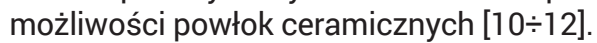

Jeśli jednocześnie ze zużyciem ściernym, adhezyjnym i zmęczeniowym występuje zużycie korozyjne na miękką fazę metaliczną stosuje się Co bądź Ni a natryskane elementy mogą pracować w temperaturach podwyższonych.

Gdy elementy są eksploatowane w temperaturach około $1000{ }^{\circ} \mathrm{C}$ na fazę miękką należy stosować Co lub NiAl, zaś w temperaturach $1300^{\circ} \mathrm{C}$ i wyższych należy stosować $\mathrm{NiCr}$.

Przyjmuje się powszechnie, że odporność na zużycie ścierne wzrasta ze zwiększaniem ziarnistości materiałów twardych i ich udziału w cermetalowych mieszaninach. Ilość metalicznego dodatku tworzącego osnowę winna być tak dobrana by twarde ziarna były dobrze otoczone osnową (by tkwiły w osnowie). W powłokach natryskiwanych na elementach narażonych jedynie na zużycie ścierne przy minimalnym oddziaływaniu udarów i nacisków zawartość fazy twardej winna być duża, a udział metalicznego dodatku winien wynosić zale-

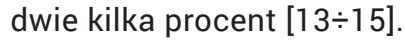

Najlepsze wyniki osiągnięto stosując powłoki cermetalowe zawierające: $\mathrm{Cr}_{3} \mathrm{C}_{2}+8 \% \mathrm{Co}$, WC $+8 \% \mathrm{Co}, \mathrm{Al}_{2} \mathrm{O}_{3}+10 \% \mathrm{NiAl}$ bądź $\mathrm{Cr}_{2} 3_{2}+10 \% \mathrm{NiAl}$ - tablica I.(poz. 3-4, 7-8, 10, 12). 
Przy wzroście siły nacisku trących się elementów w charakterze materiału osnowy stosowany jest NiCr w ilości do $25 \%$. Taki skład cermetalowej mieszaniny okazał się szczególne przydatny do natryskiwania np. ślimaków do wtryskarek, pił tarczowych - tablica I. (poz.1,11-13).

W przypadkach zużycia zmęczeniowego (łopatki wentylatorów, ssaw aglomeracyjnych, bądź śrutownic) najbardziej przydatnymi okazały się: w charakterze fazy twardej węgliki o małej ziarnistości $(38-63 \mu \mathrm{m})$ zaś w charakterze osnowy Al i Ni - umożliwiające uelastycznienie osnowy. Ze zmniejszeniem ziarnistości fazy twardej wzrasta powierzchnia jej rozwinięcia (powłoki). Uderzające o rozwiniętą powierzchnię fazy twardej ścierniwo wywołuje mniejsze zużycie powłoki.

Z przytoczonych wyników eksploatacji elementów natryskanych zróżnicowanymi mieszaninami materiałów ceramicznych i metalicznych o różnej wielkości ziaren (klas ziarnowych) wynika, że chcąc uzyskać większą odporność na ścieranie z jednoczesną możliwością zwiększenia obciążenia należy drogą eksperymentów dobrać wielkość ziaren i ilości fazy twardej zaś w charakterze osnowy stosować materiały względnie miękkie i stosownie do potrzeb - odporne na korozję tablica I. (poz. 9, 16).

\section{Charakterystyka metod pomiarowych procesów ścierania i wyniki pomiarów}

Pomiary zużycia ścierającego próbek stalowych oraz powłok natryskanych plazmowo (na identyczne próbki) zrealizowano na maszynie tarciowo zużyciowej.

Tablica I. Wybrane przykłady zastosowania powłok dla ochrony przed ścieraniem i erozją

Table I. Selected examples of an application of wear protection coatings

\begin{tabular}{|c|c|c|c|c|}
\hline \multirow{2}{*}{ Lp. } & \multicolumn{2}{|c|}{ Wyszczególnienie } & \multirow{2}{*}{ Przyczyny zużycia } & \multirow{2}{*}{ Uzyskane wnioski } \\
\hline & Zakład & Element & & \\
\hline 1 & $\begin{array}{c}\text { Huty: Częstochowa, Zawiercie, } \\
\text { Bankowa, Batory ,Pokój, } \\
\text { Bobrek, Zygmunt, Łabędy }\end{array}$ & $\begin{array}{l}\text { piły tarczowe do cięcia } \\
\text { wyrobów walcowanych }\end{array}$ & \multirow{7}{*}{ ścieranie } & $\begin{array}{l}\text { 2-11 x wzrost trwałości } \\
\text { obniżenie hałasu } \\
\text { w czasie cięcia }(\sim 35 \mathrm{~dB})\end{array}$ \\
\hline 2 & Kombinat Opakomet Zawiercie & przekładnie ślimakowe & & 7x wzrost trwałości \\
\hline 3 & $\begin{array}{l}\text { Zakłady Przem. Lniarskiego } \\
\text { Częstochowa Stradom, } \\
\text { Zakłady Włókien Sztucznych } \\
\text { Cehitex-WistomTomaszów } \\
\text { Mazowiecki }\end{array}$ & $\begin{array}{l}\text { rolki aluminiowe, talerzyki prze- } \\
\text { wijarek, naprężacze, } \\
\text { prowadnice nici } \\
\text { i inne elementy }\end{array}$ & & 100x wzrost trwałości \\
\hline 4 & Huta Częstochowa & $\begin{array}{c}\text { płyty cierne wozów } \\
\text { gaśniczych, płyty cierne } \\
\text { zrzutni koksu }\end{array}$ & & \multirow{3}{*}{ 2x wzrost trwałości } \\
\hline 5 & Zakłady TONSIL Września & matryce do produkcji membran & & \\
\hline 6 & Elektrociepłownia Rzeszów & $\begin{array}{c}\text { elementy tworzące } \\
\text { powierzchnie robocze młynów } \\
\text { weglowych }\end{array}$ & & \\
\hline 7 & Kopalnia Trzebionka & wały pomp flotacyjnych & & 6x wzrost trwałości \\
\hline 8 & $\begin{array}{l}\text { Huta Ferum, Kopalnia Rudy } \\
\text { Polkowice }\end{array}$ & tuleje pomp & $\begin{array}{l}\text { ścieranie i zużycie } \\
\text { kawitacyjne }\end{array}$ & $\begin{array}{l}\text { 1,5-1 wzrost trwałości } \\
\text { 2,3-x wzrost trwałości }\end{array}$ \\
\hline 9 & Elektrownia Rybnik & $\begin{array}{l}\text { korpusy uszczelniaczy } \\
\text { wodorowych }\end{array}$ & $\begin{array}{c}\text { ścieranie } \\
\text { i międzykrystaliczna } \\
\text { korozja wodorowa }\end{array}$ & w eksploatacji \\
\hline 10 & $\begin{array}{c}\text { Huta Zawiercie } \\
\text { Politechnika Wrocławska }\end{array}$ & wirniki pomp wodnych & $\begin{array}{l}\text { ścieranie i zużycie } \\
\text { kawitacyjne }\end{array}$ & $\begin{array}{l}\text { 11-13x wzrost trwałości } \\
\text { 3-4x wzrost trwałości }\end{array}$ \\
\hline 11 & Huta Częstochowa & wirniki ssaw aglomeracyjnych & silne zużycie erozyjne & 3,2x wzrost trwałości \\
\hline 12 & Huta Zawiercie & $\begin{array}{l}\text { wirniki wentylatorów } \\
\text { na stanowiskach do cięcia } \\
\text { wyrobów walcowanych }\end{array}$ & $\begin{array}{l}\text { silne zużycie } \\
\text { erozyjne przez } \\
\text { metaliczne wióry }\end{array}$ & $4 x$ wzrost trwałośc \\
\hline 13 & Fabryka Maszyn Zawiercie & wirniki śrutownic & ścieranie erozyjne & 5,5 x wzrost trwałości \\
\hline 14 & Fabryka Obrabiarek Poręba & $\begin{array}{l}\text { wrzeciona tokarń loża tokarń } \\
\text { i koła sterujące }\end{array}$ & $\begin{array}{l}\text { zużycie ścierające } \\
\text { i wady odlewnicze }\end{array}$ & w eksploatacji \\
\hline 15 & Huty: Sendzimir, Katowice & $\begin{array}{c}\text { ściany kotłów odzysknicowych } \\
\text { nad konwertorami }\end{array}$ & korozja i ścieranie & $\begin{array}{l}\text { po 2,5 letniej } \\
\text { eksploatacji stan } \\
\text { powłok dobryw } \\
\text { eksploatacji }\end{array}$ \\
\hline 16 & Elektrownia Bełchatów & $\begin{array}{l}\text { nakładki antyerozyjne leja } \\
\text { opadowego kotła }\end{array}$ & korozja i ścieranie & w eksploatacji \\
\hline
\end{tabular}


W badaniach tarciowo-zużyciowych wyznaczono ubytek masy ścieranych próbek stalowych (seria I), a następnie ścieranych powłok tj.: ceramicznych (seria II) i cermetalowych (seria III).

Natryskane powłoki posiadały grubość $0,3 \mathrm{~mm}, 0,4 \mathrm{~mm}$ i 0,5 mm.

Pomiar zużycia erozyjnego próbek stalowych (odcinki rur wykonanych ze stali kotłowej) oraz próbek z natryskanymi powłokami ceramicznymi i cermetalowymi przeprowadzono na stanowisku obróbki strumieniowo-ściernej. Przy stałych parametrach pracy pistoletu piaskującego (ciśnienie i wydajność) erodowano elekrokorundem powierzchnie próbek przez 900 sekund i wyznaczano ubytek masy próbki po tym czasie.

\section{Odporność próbek stalowych oraz badanych powłok na zużycie ścierne}

Odporność na ścieranie badanych rodzajów powłok i stalowych próbek oznaczono na maszynach tarciowo - zużyciowych. Wyniki pomiarów przedstawiono na rysunku 2.

Stalowe próbki bez powłok oraz próbki z natryskanymi powłokami z: $\mathrm{WC}+8 \% \mathrm{Co}, \mathrm{Al}_{2} \mathrm{O}_{3}, \mathrm{Cr}_{2} \mathrm{O}_{3}$ ścierano przeciwpróbkami wykonanymi ze stali St3s. Przeciwpróbki obciążono ciężarem 500 N, a droga tarcia wynosiła 4000 m. Wyznaczano ubytek masy (względnej) w gramach.

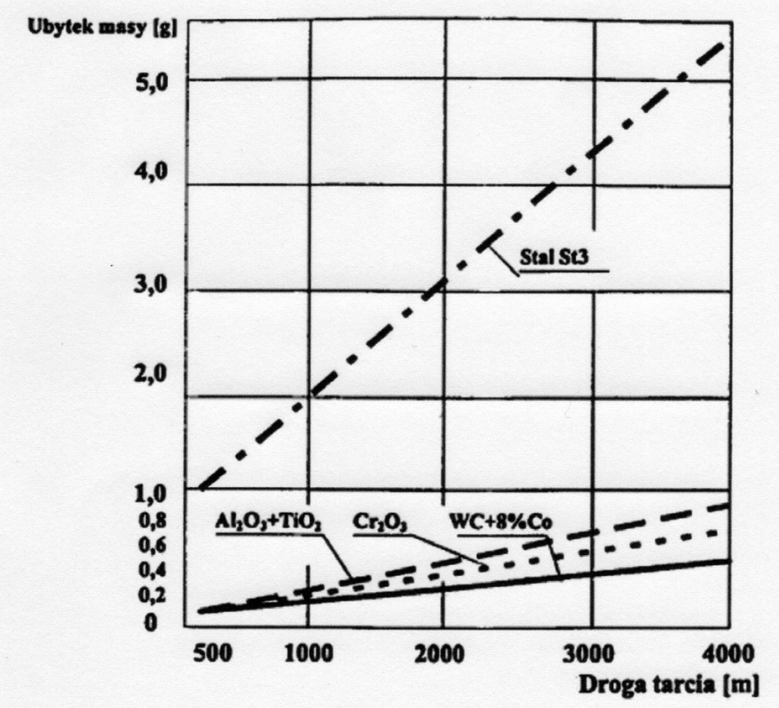

Rys. 2. Wyniki odporności na ścieranie próbek stalowych oraz powłok Fig. 2. Caparysion of wear and friction resistance steal samples whit or without coatings

Wyniki badań wykazały, że powłoki węglikowe zużywały się ponad 10-krotnie wolniej, a powłoki z tlenku glinowego bądź chromowego zużywały się 8-krotnie wolniej od stali.

W przypadkach ścierania powłok tlenkowych wzrost temperatury nawet do $1000^{\circ} \mathrm{C}$ nie powodował zmiany odporności powłok na ścieranie.

Nie stwierdzono wpływu podgrzania powłok węglikowych do temperatury $600^{\circ} \mathrm{C}$ na zmianę ich odporności na zużycie ścierne. Ustalono, iż istotny wpływ na wzrost odporności na ścieranie powłok węglikowych wywarła obecność argonowej warstwy osłaniającej strumień plazmy w procesie natryskiwania powłok. I tak pomiary zawartości tlenu wykazały, iż w przypadku stosowania takiej osłony zawartość tlenu w plazmie zmniejszyła się 3-krotnie.

Jednocześnie wyniki pomiarów ścieralności powłok (węglikowych) wykazały ponad 50\% wzrost wartości badanego parametru. Przeciętna mikrotwardość powłok węglikowych wynosi $19000 \mathrm{~N} / \mathrm{mm}^{2}$, powłok tlenkowych wytworzonych z tlenku glinu bądź chromu około $14000 \mathrm{~N} / \mathrm{mm}^{2}$, zaś warstwy podkładowo-wiążącej wytworzonej z NiCr poniżej - 4000 N/mm²

\section{Odporność na zużycie erozyjne}

Na rysunku 3 przedstawiono wyniki pomiarów odporności powłok na zużycie erozyjne.

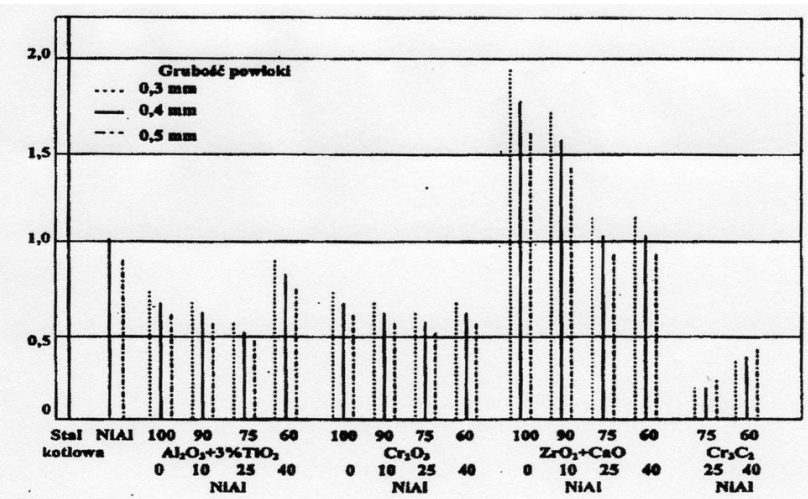

Rys. 3. Wyniki odporności na zużycie erozyjne próbki stalowej oraz powłok

Fig. 3. Results of wear and erosion resistance on steal samples before and after spray modification

Najwyższą odporność na erozję wykazują powłoki natryskane z mieszanin węglika chromu z aluminkiem niklu. Nieco mniejszą odporność wykazały cermetalowe powłoki wytworzone $\mathrm{z}_{2} \mathrm{O}_{3}+\mathrm{NiAl}$. Zbliżonymi wartościami odporności erozyjnej odznaczają się powłoki natryskane z miesza$\operatorname{nin} \mathrm{Cr}_{2} \mathrm{O}_{3}+\mathrm{NiAl}$. Dla wymienionych rodzajów powłok odporność erozyjna okazała się dużą w stosunku do odporności wykazywanej przez stal kotłową. Jedynie powłoki natryskane z tlenku cyrkonowego bądź cermetali wytworzonych na jego bazie cechuje niska odporność erozyjna.

\section{Dobór powłok ograniczających erozje powierzchni ogrzewalnych kotłów}

Powierzchnie ogrzewalne kotłów tj. rury ekranowe tworzące komorę paleniskową oraz powierzchnię przegrzewaczy pary, sfery przypalnikowe oraz rury kotłów fluidalnych ulegają intensywnej erozji. Na przykład w kotłach opalanych węglem w wyniku spalania tworzy się popiół, którego część jest unoszona przez spaliny. Popiół głownie składa się $\mathrm{z}$ ziaren $\mathrm{SiO}_{2}, \mathrm{Al}_{2} \mathrm{O}_{3}$, które podczas ruchu powodują erozję powierzchni ścian, część unoszonego popiołu osadza się na elementach kotła. Do usuwania osadzającego się popiołu stosuje się strumień pary podawany przez zdmuchiwacze. Nacierająca z dużą prędkością para wywołuje dalsze erodowanie powierzchni kotła. Dane eksploatacyjne niektórych elektrowni opalanych węglem wykazują, iż prędkość niszczenia rur wynosi do $3 \mathrm{~mm} /$ rok.

Fabryki kotłów oraz elektrownie i elektrociepłownie żądają by powłoki natryskiwane na rury posiadały minimalną mikrotwardość $5400 \mu \mathrm{HV}$ (obciążenie $3000 \mathrm{~N}$ ). Wychodząc na przeciw tym wymaganiom Autorzy pracy dokonali doboru rodzaju powłok dla sprecyzowanych żądań. Badaniom poddano powłoki wielowarstwowe.

Powłokę oznaczoną N natryskano jako dwuwarstwową (rys. 4) warstwę wiążącą wykonano z aluminku niklu, natomiast warstwę zewnętrzną (roboczą) natryskano z nichromu. Uzyskano następujące wyniki pomiarów mikrotwardości:

- mikrotwardość stalowego podłoża (stal kotłowa K14) - $2000 \mu \mathrm{HV}$ (obc. $3000 \mathrm{~N}$ ),

- mikrotwardość warstwy podkładowej (aluminek niklu) - $4260 \mu \mathrm{HV}$ (obc. 3000N),

- mikrotwardość warstwy zewnętrznej (nichrom) - 6300 $\mu \mathrm{HV}$ (obc. 3000N), 
Powłokę węglikową oznaczoną literą C (rys. 5) wykonano również jako dwuwarstwową. Wyniki badań wykazały następujące wartości mikrotwardości:

- mikrotwardość stalowego podłoża (stal kotłowa K14) - $2000 \mu \mathrm{HV}$ (obc. 3000N),

- mikrotwardość warstwy podkładowej (50\% NiAl-50\% $\mathrm{NiCr}$ ) $-7040 \mu \mathrm{HV}$ (obc. $3000 \mathrm{~N}$ ),

- mikrotwardość warstwy zewnętrznej (Cr2C3+NiAl ) - 9590 $\mu \mathrm{HV}$ (obc. 3000N).

Powłoką typu $\mathrm{C}$ natryskano $\mathrm{m} / \mathrm{i}$ :

- dolną część kotła odzysknicowego zabudowanego nad konwertorem stalowniczym dla ochrony przed ścieraniem. Po ponad 2 letniej eksploatacji stwierdzono obecność powłok na natryskanych fragmentach powierzchni, co stanowi podstawę kontynuacji dalszych prac $\mathrm{w}$ tym zakresie.

- Konfuzor zwężki Venturii oczyszczalni gzów konwertorowych uzyskując ponad 3-krotne wydłużenie pracy elementu.

Poprzez kształtowanie grubości natryskiwanych powłok można osiągać pożądany czas eksploatacji elementów urządzeń przemysłowych.

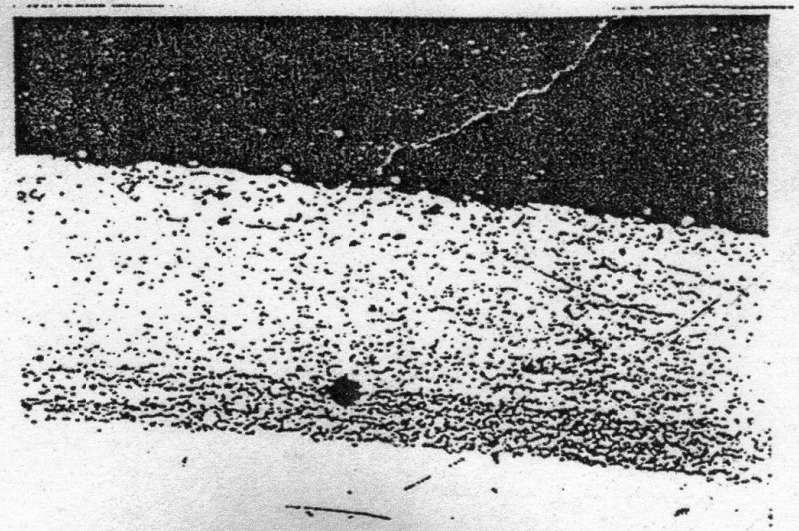

Rys. 4. Fotografia mikrostruktury powłoki typu N (100x)

Fig. 4. Microstructure of $\mathrm{N}$ type coating

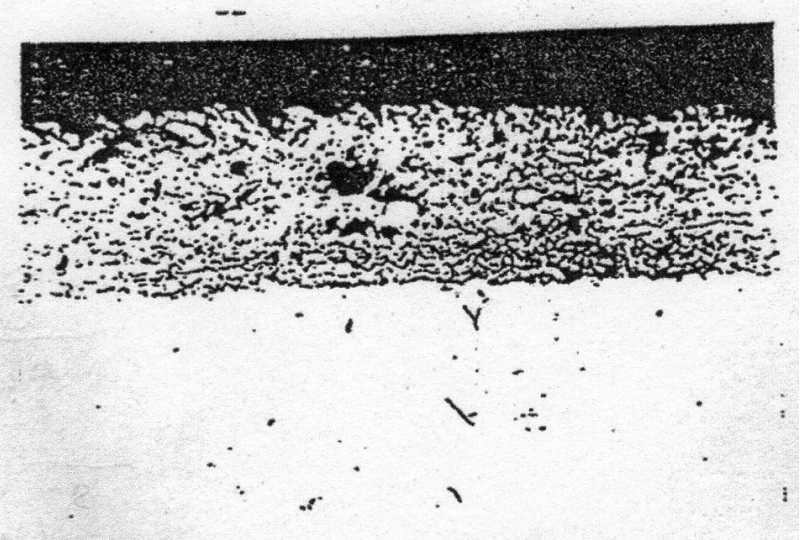

Rys. 5. Fotografia mikrostruktury powłoki typu C (100x)

Fig. 5. Microstructure of $C$ type coating

\section{Stwierdzenia i wnioski}

Poznanie mechanizmu zużycia elementów maszyn i urządzeń oraz wartości parametrów przy których te procesy zachodzą umożliwia dobór rodzaju powłok i ukształtowania ich własności w aspekcie stwierdzenia ich przydatności do stawianych im zadań.

Powłoki natryskiwane plazmowo cechuje kilkukrotnie większa mikrotwardość oraz wielokrotnie większa odporność na zużycie niż podłoże na które je natryskano.

Wyniki eksploatacji przemysłowych elementów maszyn i urządzeń uzasadniają celowość wytwarzania na ich powierzchniach powłok ceramicznych i cermetalowych.

\section{Literatura}

[1] St. Morel: Powłoki natryskiwanie cieplnie Monografia. Wyd. WIPMiFS Politechnika Częstochowska, Częstochowa 1990.

[2] S. Morel: Application of Plasma-Sprayed Coatings in Heat Absorption by Radiated Walls. Archive of Energetics / Archiwum Energetyki T. 41 nr 3-4, 2011, s. 111-126

[3] A. Hernas, J. Dobrzański: Trwałość i niszczenie elementów kotłów i turbin parowych. Wyd. Politechniki Śląskiej 2003, str. 24-45.

[4] T. Burakowski, T. Wierzchoń: Inżynieria powierzchni metali. Wyd. WN-T Warszawa 1995.

[5] B.G. Abrgmowicz, W.t. Goldsztein: Intienisifikacja tiepłobmiena izłuczeniem s pomoszczju pokrytej. Wyd. Eniergia, Moskwa 1977, str. 26-39.

[6] T. Węgrzyn, J. Piwnik: Low alloy welding with mocro-jet cooling. Archives of Metllurgy and Materials, vol. 57, Iss. 2, 2012.

[7] S. Morel: Zastosowanie powłok plazmowych w hutniczych urządzeniach grzewczych. Hutnik-Wiadomości Hutnicze R. 78, nr 5, 2011, s. 449-451.

[8] S. Morel: Koszty wytwarzania powłok metodami natryskiwania cieplnego. Przegląd Spawalnictwa, R. 84, nr 8, 2012, s. 7-10.

[9] S. Morel, J. Jasiński, L. Jeziorski: Powłoki natryskiwane plazmowo na elementach urządzeń do fluidalnej obróbki cieplnej. Inżynieria Materiałowa, R. 33, nr 5 (189), 2012, s. 456-459.

[10] T. Hejwowski: Nowoczesne powłoki nakładane cieplnie odporne na zużycie ścierne i erozyjne. Wyd. Politechnika Lubelska 2013.

[11] A. Hermas, B. Chmiela: Untypical bromine corrosion in bolers co-firing biomass. Journal of Achievements in Materials and Manufacturing Engineering 2012, vol. 54, nr 1, str. 5866.

[12] W. Bielikowski: Korozja powierzchni ogrzewalnych kotłów przy slaniu niskoemisyjnym. Energrtyka, nr 1, 2000, str. 45-51.

[13] J.C. Nava: Cost-effective thermal spray coatings fort he boiler industry. Welding Journal, 2009, vol. 99, No 7.

[14] M. Zubielewic Kierunki badań i rozwoju powłok ochronnych. Ochrona przed korozja, nr 4, 2006, str. 97-98.

[15] http://www.worldsteel.org/media-centre/press-releases/2012/122012-crude-steel.html; (14.02.2013).

[16] Steel Heat Treatment Handbook. Metallurgy and Technologies, in: G.E. Totten, (Eds.), CRS Taylor \& Francis Group, 2006.

[17] M. Kaviany. Principles of Heat Transfer in Porous Media. 2nd edition, Springer, New York, 1995

[18] R. Singh: Thermal Conduction Through Porous System, in: A. Öchsner, et al. (Eds.), Cellular and Porous Materials: Thermal Properties Simulation and Prediction, WILEY-VCH Verlag GmbH \& Co, KGaA, Wenheim, 2008, pp. 199-238.

[19] J.H. Lienhard: A Heat Transfer Textbook. Third Edition. Phlogiston Press, Cambridge Massachusetts, 2010.

[20] F.P. Incropera, D.P. DeWitt: Fundamentals of Heat and Mass Transfer, 6th edition, New York, Wiley 2007.

[21] E. Kostowski: Heat flow. Silesian University of Technology Publishing House, Gliwice 2000.

[22] M. Bahrami, M.M Yovanovich, J.R. Culham: Effective thermal conductivity of rough spherical packed beds, Int. J. Heat Mass Tran. 49 (2006), 3691-3701 